\title{
Kurt Lüscher, Andreas Hoff, Giovanni Lamura \& Marta Renzi, Mariano Sánchez, Gil Viry \& Eric Widmer, Andrzej Klimczuk, Paulo de Salles Oliveira, Generations, intergenerational rela- tionships, generational policy: A multilingual compendium, Uni- versität Konstanz, Konstanz 2015, ss. 192.
}

Relacje międzypokoleniowe są nieodłącznym elementem ludzkiej egzystencji. Bez względu na okres historyczny czy krąg kulturowy towarzyszą one większości sytuacji społecznych, które zachodzą zarówno na gruncie życia prywatnego, jak i publicznego. Można zatem stwierdzić, że są to relacje społecznie wszechobecne, relacje, które - w mniej lub bardziej bezpośredni sposób - oddziałują na funkcjonowanie nie tylko poszczególnych osób, ale i zbiorowości, pociągają za sobą istotne konsekwencje cywilizacyjne, kulturowe, społeczne, ekonomiczne czy polityczne. Należy jednak w tym miejscu podkreślić, że relacje te charakteryzują się nie tylko heterogenicznością, wieloaspektowością i wielowymiarowością, ale również kontekstualnością* Sprawia to, że uprawomocnionym wydaje się twierdzenie, w myśl którego wszechstronne studia teoretyczne i praktyczne dotyczące problematyki relacji międzypokoleniowych cechować powinny się interdyscyplinarnością, a jednocześnie uwzględniać pespektywę międzykulturową, w tym zawierać odniesienia do międzynarodowej literatury przedmiotu.

W nurt komparatystycznego dyskursu dotyczącego kwestii międzypokoleniowych wpisuje się recenzowana publikacja, której autorami są członkowie Międzynarodowej Sieci Relacji Międzypokoleniowych (Generationes). Recenzowana pozycja to wielojęzyczne kompendium zawierające rzeczowy opis koncepcji i terminologii z obszaru badań nad pokoleniami czy relacjami międzypokoleniowymi. Prezentowane wydanie, w którym uwzględniono siedem języków: angielski, francuski, niemiecki, włoski, hiszpański, polski i portugalski, opublikowane zostało wyłącznie w wersji elektronicznej i dostępne jest za pośrednictwem sieci Internet, m.in. na stronie: https://depot.ceon.pl/bitstre-

* M. Kilian, Edukacja międzypokoleniowa wobec wyzwań wspótczesności, „Forum Pedagogiczne" 2011, nr 2, s. 97-118. 
am/handle/123456789/7783/Luescher-Kompendium_7sprachig-komplett_ online_15-10-2015.pdf? sequence=18isAllowed=y.

Dużym walorem omawianego wydawnictwa jest jego czytelny i funkcjonalny układ. Książka została zaprojektowana w taki sposób, aby pozwalała na stosowanie jej do tłumaczenia zaprezentowanych w niej pojęć. W zamieszczonych w niej siedmiu tekstach w różnych językach omawiane są te same treści, które uporządkowane zostały w tej samej kolejności i zsynchronizowane według numeracji akapitów, co ułatwia bezpośrednie porównania. Należy jednak w tym miejscu odnotować, że celem recenzowanej pozycji nie jest tylko bycie użytecznym narzędziem translatorskim. Powstała ona również po to, żeby przyczynić się do pobudzenia i poszerzenia międzynarodowej debaty na temat relacji międzypokoleniowych, w tym inspirować do spojrzenia na tę problematykę przez pryzmat różnic wynikających z odmiennych kontekstów kulturowych.

Realizacji zaprezentowanego celu sprzyja spójność siatki pojęciowej recenzowanej publikacji, a także sposób, w jaki została ona ujęta. Na szczególną uwagę zasługuje zwłaszcza przyjęta przez autorów perspektywa rozumienia terminu „pokolenie”, która stanowi punkt wyjścia pozwalający na określenie ram koncepcyjnych do analiz relacji (między)pokoleniowych. Perspektywa ta stanowi formę porozumienia między dwoma podejściami poznawczymi: powszechnie przyjmowanym w polskiej literaturze przedmiotu podejściem koncentrującym się na relacjach rodzinnych*, w którym pokolenia definiowane są jako „ogniwa w ciągu genealogicznym”, oraz ujęciem historycznym, w którym pokolenia postrzegane są jako „[...] kategorie społeczne lub „grupy” porównywalne do klas społecznych" (s. 145). Co ważne, wyróżnia się ona tym, że nakreślona została wokół założenia o istnieniu związku między przynależnością do pokolenia a procesem konstruowania tożsamości - tak indywidualnej, jak i zbiorowej, oraz wzbogaceniem jej o wymiar polityczny.

Uwzględniając przyjętą przez siebie perspektywę rozumienia pojęcia „pokolenie”, autorzy poszczególnych części językowych zawartych w publikacji dokonują interesujących poznawczo rozważań dotyczących aktualno-

* Por.: L. Dyczewski (2002), Więź między pokoleniami $w$ rodzinie, Lublin; K. Linowski, E. Lisowska, K. Gąsior (red.) (2007), Seria Rodzina-Pokolenia-Przekazy, t. 1: Dziadkowie, rodzice, dzieci. Transmisja międzypokoleniowa, Kielce; T. Rostowska (2001), Konflikt międzypokoleniowy w rodzinie. Analiza psychologiczna, Łódź; Taż (1995), Transmisja międzypokoleniowa $w$ rodzinie w zakresie wybranych wymiarów osobowości, Łódź; M. Sitarczyk (2002), Międzypokoleniowa transmisja postaw wychowawczych ojców, Lublin; P. Szukalski (2015), Relacje międzypokoleniowe we wspótczesnych polskich rodzinach, Łódź; W. Wrzesień (2003), Jednostka-rodzina-pokolenie. Studium relacji międzypokoleniowych w rodzinie, Poznań; J. Zamorski (2009), Międzypokoleniowy przekaz wartości w rodzinie, Rzeszów. 
ści relacji międzypokoleniowych, ich wymiarów oraz związków z określonymi strukturami społecznymi. Odnoszą się do zagadnienia wielopokoleniowości, konfliktu, solidarności i ambiwalencji międzypokoleniowej, a także charakteryzują elementy ładu i polityki relacji międzypokoleniowej, biorąc przy tym pod uwagę: zróżnicowanie płci, generatywność, kapitał społeczny czy zagadnienie sprawiedliwości/równości/uczciwości. W podsumowaniu proponują czytelny schemat zintegrowanej polityki relacji międzypokoleniowych. Analiza tego wykresu przywodzi na myśl tezę, że indywidualne i zbiorowe relacje międzypokoleniowe $\mathrm{z}$ reguły występują $\mathrm{w}$ parze $\mathrm{z}$ procesami uczenia się. Dlatego tak ważne wydaje się zintensyfikowanie teoretycznych i praktycznych analiz dotyczących międzypokoleniowego uczenia się, inicjowanie przedsięwzięć, które bazując na (auto)refleksyjności i otwartości na Innego, pozwalałyby na świadome uczestnictwo w tego typu procesie edukacyjnym*.

Kolejnym atutem recenzowanej pozycji, sprzyjającym pełnieniu przez nią funkcji katalizatora wymiany międzykulturowej w kwestiach międzypokoleniowych, jest jej egalitarność. Wyrazem tej własności jest wspomina już forma publikacji jako kompendium - zwiększająca jego dostępność, a także przystępność zastosowanego w nim języka, który wydaje się być zrozumiałym nie tylko dla teoretyków, ale również niewdrożonych w studia literaturowe praktyków. Praktycznej realizacji zdefiniowanej funkcji sprzyjać może również zabieg wieńczenia wchodzących w skład prezentowanej książki tekstów w poszczególnych językach wykazem ważniejszych publikacji dotyczących problematyki międzypokoleniowości, które ukazały się w ostatnich latach w danym języku.

Podsumowując, można stwierdzić, że recenzowana publikacja ze względu na podjętą w niej problematykę oraz sposób jej ujęcia i prezentacji wpisuje się w nurt analiz poświęconych życiu w postmodernistycznych społeczeństwach, gdzie kluczową pozycję zajmuje pytanie o to, jak ludzie rozwijają swoją tożsamość indywidualną i zbiorową. Pozycja ta udowadnia, że procesy tłumaczenia i adaptacji tekstów sprzyjają badaniu, a także dokumentowaniu różnorodności kultur czy języków. Pozwala dostrzec wielość obszarów zachodzenia relacji międzypokoleniowym oraz towarzyszących im procesów, w tym również tych o charakterze edukacyjnym. Tym samym lektura recenzowanej książki stanowi inspirujące do dalszych poszukiwań, a poprzez swoją wielojęzyczność wspiera rozumienie zjawisk i analiz teoretycznych $\mathrm{w}$ dziedzinie międzypokoleniowego uczenia się w wielokulturowym świecie.

Kinga Majchrzak

* Por.: M. Muszyński (red.) (2014), Międzypokoleniowe uczenie się, Łódź. 